\title{
WRITING IN ABSENTIA: NOSTALGIA AND ANTI- NOSTALGIA IN THE ESSAYS OF GEORGI MARKOV
}

\author{
Tom Phillips, University of Sofia "St Kliment Ohridski," \\ t.phillips18@btinternet.com
}

\author{
DOI: 10.31902/fll.31.2020.5 \\ UDK: 821.161.1.09 Markov G.
}

\begin{abstract}
Between 1975 and his assassination in 1978, the Bulgarian journalist Georgi Markov wrote more than 130 radio reports about life in Bulgaria. These, however, are not news reports in the conventional sense. They are a form of autobiographical reportage and, as such, don't focus so much on contemporary events in Bulgaria, as on Markov's own experiences and encounters in the homeland he eventually found it necessary to leave in 1969. Thanks to the negative image they construct of Bulgaria during the 1950s and 1960s, these reports - or, perhaps more accurately, radio essays - appear to represent a wholly anti-nostalgic form of reportage and memoir in line with the conventions of what we might call dissident narrative. At the same time, however, they exist on a more complex, more nuanced emotional terrain and, in recognising this, this paper argues that Markov's work in these essays should more rightly, more accurately be regarded as belonging to the literature of exile rather than as simple polemic.
\end{abstract}

Keywords: nostalgia, home, journalism, autobiography, Bulgaria, communism, dystopia, utopia.

Nostalgia is a not word that's often associated with the Bulgarian author, scriptwriter and journalist Georgi Markov. A noted dissident voice during Bulgaria's communist period, especially after he left for Italy and then Britain in 1969, his most well-known and, in some ways, most substantial body work consists of the series of radio broadcasts which, after a brief stint at the BBC World Service, were broadcast on Radio Free Europe. Now collected and published posthumously as Задочни репортажи за задочна България - a title which might be translated as Reports in absentia on an absent Bulgaria - these broadcasts or, more accurately, radio essays construct an image of Bulgaria during the 1950s and 1960s which, on the face of it, is unremittingly negative. ${ }^{1}$ It is world of bleak absurdities, cruel

\footnotetext{
${ }^{1}$ Georgi Markov, Задочни репортажи за задочна България (Reports in absentia on an absent Bulgaria) (Sofia: Ciela, 2016).
} 
injustices, cults of personality, hypocrisy, and endless frustrations even for those who, like Markov, were members of a relatively privileged elite. Were they fiction, these Reports in absentia would almost certainly be classified as dystopian - and, indeed, the Bulgaria that Markov portrays bears more than a passing resemblance to that of 1984 by George Orwell (whom he cites on a number of occasions). Likewise, Markov's metaphor of choice for describing the situation of ordinary citizens in communist-era Bulgaria - под капака (under the lid) - clearly echoes the title of Ivan Vazov's famous 1893 novel about the Ottoman occupation, Под uzomo or Under the Yoke, the implication being that the communist regime is as tyrannical, repressive and invasive as the imperial power which occupied Bulgaria from the late 14 th to the late 19 th/early 20 th centuries. ${ }^{2}$

Markov's detailed critique of the ideology and practice of the Bulgarian regime, however, is not limited to theoretical or philosophical issues. The broadcasts are essentially autobiographical, drawing on Markov's own experiences as a young writer who, despite his non-conformist views, was accepted into the Bulgarian Writers' Union and enjoyed, not only the guaranteed critical acclaim which came with being a member, but also a range of privileges accorded to him by the state. Whilst the broadcasts - when read in the order collected in the two volumes of задочни репортажи за задочна България - give the impression of being a coherent and comprehensive analysis of communist policy towards all aspects of life within the country - from construction projects to culture, manufacture to tourism etc - they are more often than not focused on personal experience, empirical observation or specific details of everyday life. Here, too, we might find comparisons with Orwell especially the latter's columns published under the generic title "As I Please" in leftwing newspaper Tribune. ${ }^{3}$ The two writers' approach to reportage is grounded in a concern with and respect for the observable manifestations of political decisions in their own and other people's immediate circumstances and experience. We might speculate, in fact, that what ultimately led to Markov's assassination in London in 1978

\footnotetext{
${ }^{2}$ Markov is not alone in identifying similarities between a communist regime and an imperial occupation: Albanian author Ismail Kadare also uses the Ottoman occupation of Albania as an allegorical representation of its post-WW2 communist regime, most notably in The Siege (1970) and The Palace of Dreams (1981).

${ }^{3}$ See George Orwell, Collected Essays, Journalism and Letters, Vol. 3, As I Please, 194345, ed. Sonia Orwell (London: Secker \& Warburg, 1968) and George Orwell, Orwell in Tribune: 'As I Please' and other writings 1943-47, ed. Paul Anderson (York: Politicos, 2006).
} 
by an agent with connections to both the Bulgarian and Soviet secret services may well have been ordered, not simply because of his critique of communist ideology, but also because of his detailed description of life under the regime. Markov's "crime," in other words, wasn't merely the expression of so-say reactionary or counterrevolutionary opinions and beliefs; it was also the detailed laying bare of the myths surrounding and underpinning the "utopia" that the communist regime claimed it was creating in Bulgaria, as well as the naming of individuals he regarded as having been complicit in the creation of this fake utopia.

At the same time as documenting the construction of an authoritarian dystopia in Bulgaria in the first twenty five years after the communists took power, however, Markov's bleak and often outspoken critiques are tempered by nostalgia - for a "distant" or "absent" Bulgaria (the Bulgarian adjective задочен used in the book's title can mean either and appears in common phrases such as "distance learning" and "tried in absentia"), for his own equally "distant" or "absent" past and, perhaps less obviously, for the "distant" or "absent" idealistic version of communism which Markov seems to believe was and perhaps still might be possible, but which he subsequently sees as having been betrayed and destroyed by the Bulgarian regime itself. Indeed, there is further ambiguity in the title Задочни репортажи за задочна България where, in this context, the word 3 a could mean either "about" or "for," suggesting that Markov is not only writing about a lost homeland, a lost past, but also for a homeland (and a readership) that has been cut off from its - as it were - Bulgarian-ness by the communist regime's importation of, first, Stalinism and then other Soviet variants of post-Stalinist ideology brought in under Khrushchev and Brezhnev. If $3 a$ is taken to mean "for," the title might also suggest the conventional dedication of an elegy or a poem like Wilfred Owen's "Anthem for Doomed Youth" - as if Bulgaria is not only "distant" or "absent," but also dead and buried. The Bulgarian title, in fact, offers multiple interpretative possibilities which are themselves 'absent' from the more melodramatic title given to the English-language volume which includes translations from a selection of Markov's memoirs and radio essays: The Truth that Killed.

Here, though, I begin with the more conventional reading suggested by that English title: the descriptions of life in 1950s and 1960s Bulgaria which amount to a truth - or at least a version of it - for which a journalist like Markov might well have been killed. The representation of communist-era Bulgaria in Задочни репортажи за задочна България certainly appears to be almost wholly negative. 
Although Markov himself would benefit from being accepted into the Writers' Union unusually early in his career, thanks to the success (and ideological acceptability) of his first novel, he finds little to commend in the version of socialism that the post-war regime introduces into the country. It's a society in which Party members and ordinary Bulgarians inhabit entirely different and ruthlessly separated worlds.

In the pair of broadcasts published under the all-encompassing title "Prostitution," for example, Markov's encounters with members of the militia charged with "cleaning up the streets" and "persuading" street prostitutes to rehabilitate themselves by taking up "proper jobs" and moving into "appropriate accommodation" and with the prostitutes themselves are offset by his discovery of a different kind of prostitution catering to the "needs" of foreigners and the upper echelons of the Communist Party itself. For reasons he only comes to understand later, Markov is invited to join a small group of journalists at the militia building overlooking Lavov Most in Sofia where they will be allowed to interview a number of street prostitutes. Markov is immediately on his guard, noting that the first prostitute they're introduced to was:

a plump, rather plain woman of around 25 years, who greeted us and smiled like someone who knows the game and has agreed to play it for our benefit. She gave the colonel [of the militia] a piece of paper. This was a note of her earnings from the last month. One of the militia's most important requirements in its struggle to re-educate prostitutes is for them to have a permanent working income. We learned that this girl now lived with her mother and worked for a printing company, where she'd been placed with the help of the militia. For several years prior to this she'd wandered about the country, living wherever and with whomever she could.

"Well, are you happy now?" asked the colonel carefully.

"Oh, comrade colonel, I'm so grateful that you've returned me to life! You have no idea how much you've helped me, both you and the workers' collective [...]" she said, reciting the phrases she had learned. (Markov 545, my translation)

As other, noticeably less compliant or "re-educated" prostitutes are brought in one by one, Markov's suspicions appear to be confirmed: the militia intended the interviews as a propaganda exercise and, in reality, the much-vaunted "re-education" programme is having little or no positive effect. Irritated both by the state's claims that it is 
eliminating prostitution and its assumption that intelligent journalists and writers would accept the official line without question, Markov refuses to do so and sets out to prove that prostitution isn't a throwback to "bourgeois capitalism," but an indication of the true nature of socialist reality. During his investigation, the colonel makes a rather more candid admission than during the officially sanctioned interviews with the prostitutes:

I myself well knew about the liberal sexual relations which had revolutionarily somehow established themselves in our life, but I had no idea how far domestic prostitution had come. According to the colonel, this kind of prostitution mostly operated in two fields: with foreigners and with influential or powerful Bulgarian citizens who could pay for such services. The foreigners consisted of a significant group of Arabic-African students and all sorts of travellers from the Near East who stopped in Sofia or Plovdiv with a whole list of addresses where they could find women for a good price. [...] According to the colonel, they mostly visited married women whose husbands were either absent or had been cleverly deceived.

"Even the other half of one of our colleagues, an officer who'd been sent to train in Moscow, turned her home into a brothel. We didn't know what to do, whether to tell him or keep quiet, nonetheless - the wife of our man [...]" said the colonel.

"And what happened?" I asked out of curiosity.

"National Security sorted the situation out. They made her work for them on the promise that they would sort the business out with her husband. When he came back, they told him that his wife had to finish some work in the name of the motherland. It was hard for him, but he accepted it as a sacrifice for the country [...] Then they divorced." (Markov 552, my translation )

As in many of his other essays, Markov's principle target here is hypocrisy which, in regard to prostitution, he identifies as being both moral (public denunciation of prostitution, extensive "private" use of prostitution in managerial and administrative circles) and political (a nominally socialist regime actively constructing, not a less, but a more unequal society).

Markov finds and describes examples of such hypocrisy on the part of the regime's middle and upper echelons in numerous different 
spheres of life. There are party officials who deride the products of western capitalism as being infinitely inferior to those of socialist Bulgaria whilst at the same time doing everything, they can to lay hold of these desirable capitalist products by having them smuggled into the country. There are others who decry the "cult of personality" whilst actively engaging in the promulgation of a cult around the Bulgarian leadership. There are writers who accede to the Writers' Union and set about producing artless propaganda in exchange for privileges denied to the majority of Bulgarians: a (relatively) luxurious place to live, a car, western goods etc. Markov himself, for example, receives a villa in one of Sofia's most prestigious neighbourhoods "in the shadow of Vitosha [mountain]." Like other writers in his position, he finds himself living what he calls "a 900-metre life" - one spent almost entirely within 900 metres of the Writers' Union building in central Sofia. Inside this cocoon, with its editorial offices and writers' cafes, like the famous Бамбук (Bamboo) on the corner by the National Theatre "Ivan Vazov," Markov gains ever greater insight into the benefits enjoyed by those prepared to compromise and work within the system.

As well as describing a lifestyle which would have been almost unimaginable to many Bulgarians, however, Markov's writings about this period increasingly come to focus on the experiences of those existing outside such privileged cocoons. In two pieces paired under the title "Жилото и медът на туризма" (literally "The sting and the honey of tourism"), a phrase that alludes to and plays on the Bulgarian idiom "нито меда, нито жилото" (meaning "absolutely nothing"), ${ }^{4}$ he recounts an experiment he conducted with his family. With the Bulgarian tourist industry beginning to grow, providing a much-needed source of foreign currency, Markov decides to go on holiday, by boat down the Danube from the inland port of Vidin and then on via Ruse and Varna to the rapidly expanding resort of Sunny Beach on the Black Sea coast. Rather than use his privileged position, his influential friends and his "name" as a member of the Writers' Union to ensure the holiday runs smoothly, however, Markov chooses to travel 'incognito' - as, in other words, an 'ordinary' Bulgarian. Almost immediately he discovers that Balkan Tourist - the state agency charged with running the tourist industry - operates a two-tier system: one for foreigners (and elite Bulgarians) and another for "ordinary" customers.

\footnotetext{
${ }^{4}$ There are no readily available English-language equivalents: perhaps the closest would be something like "not a sausage," "not a dicky bird" or the less common "goose egg."
} 
Until Vidin everything went normally. However, when we arrived at the port in the evening in order to take up the cabins in which we supposed we'd be sleeping because the boat left very early in the morning - we encountered the first surprise.

"No cabins for Bulgarians!" The officer responsible announced without ceremony.

It turned out that a group of westerners - French, I think - had taken the cabins allotted to Bulgarians.

"You do understand, comrades," another member of staff explained, "that we can't pass up on western tourists like that, not when they're paying with hard currency [...] It's helping our economy." (Markov 424, my translation)

This becomes a recurrent pattern throughout the trip until, in Sunny Beach itself, they can't even find anywhere to eat with tables that are available to Bulgarians and Markov only manages to feed his hungry family with the help of a friend, one of the local barmen - albeit in a place he later describes as "one of those imaginary establishments with uncomfortable little tables, benches instead of chairs, ersatz rural walls hung with pots, a tasteless parody of national customs" (Markov 420, my translation). Either way, the experience leaves him with the clear impression that the majority of Bulgarians aren't so much secondas third-class citizens in their own country, a long way below the local elite and foreigners with hard currency. For Markov, this completes a transition which, taken as a whole, his essays record and are structured around - the transition of Bulgaria from ideological fanaticism in the early Stalinist years of the communist period, via the 1960s when the regime was forced to make compromises and abandon its former (and, in Markov's eyes, often absurd) attempts at intensive and comprehensive social engineering, to what is now usually referred to as "state capitalism" - which, again in Markov's eyes, appears to be nothing more than a very poor, very badly managed version of western capitalism with an equally unequal distribution of money and power.

Following directly on from "Жилото и медът на туризма," “Белият Мерцедес" ("The White Mercedes") recounts another story connected with Sunny Beach - that of a solitary accordion-player who appears, almost comatose, slumped in the corner of the "ersatz" establishment where Markov and his family finally managed to get something to eat. The waiter points him out, describing him as "a monument to waiting" and explaining that, for years now, he's been waiting for the eponymous "white Mercedes" to appear in the resort. 
Markov immediately realises that he knows this slightly younger man: his name is Vlado, he graduated in engineering from the same polytechnic as Markov and was one of a party of engineers who went on a camping holiday to Sunny Beach in 1959 - long before the resort itself was transformed into "a tasteless parody of national customs" for the benefit of foreign tourists. Markov too was a member of that party and recalls how they encountered a rich German woman who drove a white Mercedes and who began an affair with Vlado, even getting permission from the authorities for him to accompany her on short trips to Istanbul and Constanţa. Towards the end of the summer season, however, the German woman leaves without warning, never to return, and it turns out that Vlado has spent the intervening years waiting, absolutely convinced that she will come back. It has become his obsession and he can no longer think of anything else. Markov ends the essay with a description of his attempt to engage his former colleague in conversation:

He gives me a puzzled look, as he if he doesn't know who I am or what I want. Then, perhaps thinking that I'm one of those who continually threw him out of restaurants, he stands up clumsily and goes towards the entrance. Cars crawl along the lane in front of him. For a moment he stops. I see how his face comes to life and his body leans forward slightly, as if he doesn't want to miss the approach of the white Mercedes. (Markov 427, my translation)

Dissociated from emotion, other people, even his own former personality, Vlado exists in a form of fugue state, in which the only possible source of meaning as he sees it would be the return of the German tourist in her white Mercedes. Markov doesn't explicitly invite us to understand this story as an allegory, but the parallels between Vlado's dissociation from reality and what it might mean for an entire country to be - as the book's title has it - in absentia are suggestive. It seems entirely plausible to read Vlado's condition as both a symptom and a symbol of the fugue state that Markov believes Bulgaria itself to have entered - with the white Mercedes acting as a metaphor for the illusory salvation on which some Bulgarians have pinned their hopes for future escape from "under the lid."

\footnotetext{
${ }^{5}$ Perhaps significantly the next essay in the series is titled "Поклон пред цар долар" ("Bowing to King Dollar") and describes "the ruthless persistence" with the regime pursued "the fulfilment of its [foreign] currency plans." (Markov 451, my translation)
} 
That Markov chooses to end this report with the image of the psychologically wounded Vlado still waiting for the German woman after six or seven years ${ }^{6}$ suggests that he attached a particular importance to it. As the journalist and translator Dimitar Kenarov points out in his introduction to Задочни репортажи за задочна България:

[Markov] elevates autobiography and historical anecdote into high literature. Using novelistic narrative strategies, including plotlines, dialogue, as well as detailed descriptions of scenes and characters, Markov breaks down the barriers between creative writing and non-fiction, demonstrating that "reportage" can masterfully combine the aesthetic power of fiction with the emotional candour of factual documentary.

Throughout these reports, then, Markov deploys a repertoire of literary devices to create vivid images of life in communist Bulgaria in the 1950s and 1960s, both from the perspective of a relatively privileged elite and of those like the street prostitutes in "Проституцията" or Pencho Danchev, the worker in a tram repair shop whose long-running attempt to get permission to visit a relative in Serbia really does become the "Passport Odyssey" through Kafkaesque bureaucracy of Markov's title (“Паспортна одисея," Markov 500-525). These images enhance and underpin the emotional and psychological impact of the testimonies contained in the essays and as such serve to reinforce Markov's polemical exposure of "the truth" about Bulgaria.

To read these essays only as polemic, however, is to overlook their more nuanced autobiographical elements. As Kenarov states, Markov's essays combine the autobiographical with the historical to an unusual extent (at least for reportage of this kind) and this enables us to consider them within the context, not so much of polemical documentary, as of the literature of exile. They are, in their way, Markov's Tristia and Ovid's lines from those poem-letters written from what is now the Romanian Black Sea port of Constanţa describing how "Rome and home haunt me, all the places I know and yearn for, whatever's left of me in the City l've lost" ${ }^{8}$ might serve as an indication

\footnotetext{
${ }^{6}$ Markov doesn't give a precise date for this encounter, but it would seem to have occurred at some point during the mid-1960s.

7 Dimitar Kenarov, “Задочен репортаж за Георги Марков” (Markov 18-9, my translation).

${ }^{8}$ Ovid, Tristia, in The Poems of Exile: Tristia and the Black Sea Letters, trans. Peter Green (University of California Press: Berkeley, 2005), p. 44.
} 
of the emotional terrain which underlies many of the essays collected in задочни репортажи за задочна България - an emotional terrain which, as well as the essentially "anti-nostalgic" core representation of Bulgaria and Markov's aspiration to present "the truth," incorporates nostalgia both in the modern sense of it being "a feeling of pleasure and also slight sadness when you think about things that happened in the past" ${ }^{\prime \prime}$ and in its original meaning - pain or sickness resulting from a desire and inability to return home. ${ }^{10}$

We certainly might find traces of pleasure as well as sadness in essays like "The White Mercedes" with its evocation of a more innocent time when, in 1959, Sunny Beach had not yet become a dedicated holiday complex and remained free of the "tasteless parody of national customs" that was to come. As Markov notes: "We were still a long way from the bawling fairground of the great tourist invasion. And as in every good beginning, the food and the service were of a far higher quality" (Markov 443, my translation). And while Markov realises at the time that Vlado's affair with the German woman was probably doomed, there is no sense that he wasn't himself fascinated by her or that he anticipated the harm that her abrupt departure would cause his colleague: "We all," Markov writes, "were charmed by her affability, her generosity and maybe by the mystery surrounding her journey itself" (Markov 443, my translation). Just as Vlado 'lost' his German lover, Markov too has lost the naivety which allowed him to be charmed by a seemingly glamorous stranger, the innocence which made the sight of an expensive foreign car so alluring and, of course, the freedom from the anxiety and stress he later experiences and describes in his account of his subsequent visit to Sunny Beach in the piece "Жилото и медът на туризма."

Similarly, Markov's descriptions of friends and colleagues from the Writers' Union who share that limited, but privileged "900 metre life" and of people known and unknown that he encounters, like the dogged passport applicant Pencho Danchev, the mysterious Lyubka (a regular denizen of Sunny Beach), the unrepentantly honest street prostitute and even the indiscreet militia colonel, exhibit symptoms of nostalgia, in both senses of the word. Compared with his unsparing descriptions of the incompetent managers, corrupt officials, absurd

\footnotetext{
9 Cambridge English Dictionary online, https://dictionary.cambridge.org/dictionary/english/nostalgia, accessed 7/12/2019.

10 "Nostalgia" derives from the Greek words nostos (return home) and algos (sickness) and first acquired its "weaker" modern-day meaning in the early $20^{\text {th }}$ century. Prior to that its predominant usage was in reference to intense forms of homesickness: it concerned an absence from place as much as from time.
} 
bureaucrats and hypocritical apparatchiks, those of many other individuals are presented with a sympathy that might be connected to feelings of both sadness and pleasure - not only for friendship, but also for certain character traits that have survived and enabled their bearers to survive "under the lid" of the regime: determination, resilience, honesty, humour etc. ${ }^{11}$

Alongside the detailed descriptions of specific places, times and people, the very act of writing these essays - all 137 of them over three years, their printed versions extending to more than 1,000 pages across two volumes - attests to the degree to which Markov was haunted by thoughts of "home [...] and whatever's left of me in the City I lost." If he explicitly expresses anger, even horror, at what Bulgaria has become, ${ }^{12}$ there is also a strong sense of sorrow and sympathy for those he has necessarily had to leave behind, for 'whatever's left of me in the City I lost', for that city itself (Sofia) and for the country at large. At no point, for example, does Markov blame anyone other than the direct perpetrators of the injustices, absurdities and cruelties he describes and, in particular, those who compromise on their own principals and beliefs in the name of securing a better lifestyle, money or power. Indeed, Markov includes himself in the latter category, albeit tempering the self-accusation by documenting his difficulty in fulfilling the expectations of the Writers' Union by making the required compromises with his own work. In Bulgarian, the word which perhaps best describes much of Markov's tone is копнежmost commonly translated into English as "yearning," but with "pain," "ache," "urge," "hunger" also being possible translations: the phrase копнеж по родината specifically refers to "homesickness" and "nostalgia."

Here, though, it's important to point out that, if Markov doesn't express nostalgia for Bulgaria as it is, nor does he express for a Bulgaria in absentia which conforms to a conventional, mythical version of "traditional Bulgaria." Although he bemoans the "tasteless parody of national customs" he encounters in Sunny Beach, he doesn't yearn for a return (personal, communal, national) to traditional values,

\footnotetext{
${ }^{11}$ See, for example, the piece 'Спасителният смях' ('Laughter to the rescue') in which he celebrates the jokes spawned by various absurdities of the communist regime. Markov, pp. 115-122.

${ }^{12}$ The pieces grouped as 'Паспортният терор' ('Passport Terror'), which immediately follow the story of Pencho Danchev in 'Паспортна одисея', for example, make clear the frustration and outrage Markov - who himself desired to travel freely outside Bulgaria in the name of broadening his own cultural horizons - felt at the regime's policy of refusing passports to all but a trusted few. Markov, pp.525-40.
} 
beliefs, rituals and behaviours. There are few references to such conventional tropes in any of the essays and it is clear that the Bulgaria Markov yearns for is not that of the pre-communist era or that fabricated by sentimental nationalists. Indeed, in the earlier essays, most of which concern the rise of Stalinism and the dual cults of personality and the Soviet Union, it would appear that what Markov yearns for is, in fact, the idealism which preceded the Bulgarian turn towards Stalin and the USSR and for the radical cultural shift towards cosmopolitanism and internationalism which that might have enabled, had it not been for the harsh realities of the Cold War and its division of powers in Europe. Again, it is those whom Markov sees as having abandoned their idealism for pragmatic reasons which come in for the most hostile criticism.

In conclusion, then, we might say that Markov's Задочни репортажи за задочна България represents a work out of the ordinary in the sense that it combines the anti-nostalgia of dissident polemic with the nostalgia of the literature of exile. Indeed, the inner conflict between nostalgia and anti-nostalgia may well be one of the forces that drove Markov to write the essays in the first place. In his own introductory remarks, for example, he observes that, since leaving Bulgaria, he has been subject to two conflicting desires: one to eradicate everything about his former life in order to start anew in London and the other to remember as much as he can about that former life in order to understand himself and what has happened to his homeland. ${ }^{13}$ If there is a root cause for what I have called the emotional terrain of Markov's often uncompromising, but also often nostalgic "home thoughts from abroad," this inner conflict - which, from my own experience as someone who now lives in another country (albeit out of choice rather than necessity), is one which many cross-cultural migrants encounter - appears to be part of its underlying tectonic structure. Markov's attitude to the questions of home and exile which dominated the last period of his life might certainly be contrasted with that of another East European dissident, Milan Kundera, who, in an interview conducted in 1984 for the New York Times, brought the whole of idea of 'home' into question, saying:

"I wonder if our notion of home isn't, in the end, an illusion, a myth. I wonder if we are not victims of that myth. I wonder if our ideas of having roots - d'être enraciné - is simply a fiction we cling to," he said, adding that he had made the choice

\footnotetext{
${ }^{13}$ Markov, pp. 22-3.
} 
between living "like an émigré in France or like an ordinary person who happens to write books."

"Do I consider my life in France as a replacement, a substitute life, and not a real life? Do I say to myself: 'Your real life is in Czechoslovakia, among your old countrymen?' [...] Or do I accept my life in France - here where I really am as my real life and try to live it fully? I chose France,' he said. $^{14}$

Had Georgi Markov not been assassinated with a ricin pellet delivered via the tip of an umbrella on London's Waterloo Bridge on the 7th September 1978, Задочни репортажи за задочна България suggests that his response to this same question might have been rather different.

\section{Works Cited:}

Cain, Sian, 'Milan Kundera's Czech citizenship restored after 40 years', The Guardian, 3/12/2019, https://www.theguardian.com/books/2019/dec/03/milankundera-czech-citizenship-restored-unbearable-lightness-ofbeing, accessed 3/12/2019. Online.

Kadare, Ismail, The Palace of Dreams, trans. Barbara Bray. London, Vintage, 2008. Print.

Kadare, Ismail, The Siege, trans. David Bellos, Edinburgh, Canongate, 2008. Print.

Markov, Georgi, Задочни репортажи за задочна България (Reports in absentia on an absent Bulgaria). Sofia: Ciela, 2016. Print.

Markov, Georgi, The Truth That Killed. London, Weidenfeld and Nicolson, 1983. Print.

Orwell, George. 1984. New York: Signet Classics, 1950. Print.

Orwell, George. Collected Essays, Journalism and Letters, Vol. 3, As I Please, 1943-45, ed. Sonia Orwell. London: Secker \& Warburg, 1968. Print.

Orwell, George, Orwell in Tribune: 'As I Please' and other writings 1943-47, ed. Paul Anderson. York: Politicos, 2006. Print.

\footnotetext{
${ }^{14}$ Cited in Sian Cain, 'Milan Kundera's Czech citizenship restored after 40 years' in The Guardian, 3/12/2019, https://www.theguardian.com/books/2019/dec/03/milankundera-czech-citizenship-restored-unbearable-lightness-of-being, accessed $3 / 12 / 2019$.
} 
Ovid, The Poems of Exile: Tristia and the Black Sea Letters, trans. Peter Green. Berkeley: University of California Press, 2005. Print.

Owen, Wilfred, The War Poems, ed. Jon Stallworthy. London, Chatto \& Windus, 1994. Print.

Vazov, Ivan Under the Yoke, trans. Edmund Gosse. Milton Keynes, JiaHu Books, 2015. Print.

\section{ЗАДОЧНОТО ПИСАНЕ: НОСТАЛГИЯТА И ПРОТИВОНОСТАЛГИЯТА В ECETATA HА ГЕОРГИ МАРКОВ}

Между 1975-а г. и убийството си през 1978-а г. българският журналист Георги Марков написа повече от 130 радиорепортажи за живота в България. Обаче тези не са репортажи в обикновеният смисъл на думата. Те са вид автобиографичен репортаж и, като такъв, не съсредоточават към съвременните събития долколкото към личните опити и срещите на Марков в родината, от която найпосле трябваше да замине през 1969-а г. Благодарение на отрицателния образ на България през 50-те и 60-те, който създават те, тези репортажи - или може би по-точно радиосказки изглеждат напълно противоносталгичен вид репортажи и мемоари, написани според правилата на това, което може да се нарича дисидентския разказ. Едновременно обаче съществуват върху един по-сложен по-нюансирани емоционален терен и, като разпознава това, тази статия се опитва да покаже, че творбата на Марков в тези есета трябва да се разгледа по-вярно, по-правилно като част от литературата на изгнание и не просто като вид полемика.

Важни думи: носталгия, дом, журналистика, автобиография, България, комунизъм, антиутопия, утопия. 